УДК 94(100):[323.2:343.322]»1939/1945»:930.2(470)

DOI: 10.24919/2519-058x.6.125199

Ірина СУХОВЕРСЬКА, orcid.org/0000-0001-9326-298X аспірантка Львівського національного університету імені Івана Франка, кафедра історії Центральної та Схіної Європи, (Україна, Львів)23anuri@gmail.com

\title{
ПРОБЛЕМИ ТРАКТУВАННЯ КОЛАБОРАЦІОНІЗМУ В РОКИ ДРУГОЇ СВІТОВОЇ ВІЙНИ У СУЧАСНІЙ РОСІЙСЬКІЙ ІСТОРІОГРАФІЇ
}

У статті охарактеризовано найважливіші тендениії наукового трактування проблеми колабораціонізму в роки Другої світової війни у сучасній російській історіографії. Визначено головні ідеї та особливості історіографічного прочесу, методи історичного дослідження, вплив суспільно-політичних явищ на тематику та зміст історичних студій. Певну увагу зосереджено на аналізі взаємодії сучасної російської історіографії та державної політики пам'яті. Окреслено перспективи наукових розвідок у изьому сегменті фундаментальних досліджень.

Ключові слова: колабораціонізм, Друга світова війна, німещько-радянська війна, російська історіографія.

Iryna SUKHOVERSKA, Post-graduate student of Ivan Franko Lviv National University Department of History of Central and Eastern Europe (Ukraine, Lviv) 23anuri@gmail.com

\section{COLLABORATION PROBLEM DURING SECOND WORLD WAR IN THE CONTEMPORARY RUSSIAN HISTORIOGRAPHY}

The approaches urged researchers in the early 1990s to overcome the ideological barriers in the interpretation of collaboration problem. However, the problem of collaboration remains the most politicized topic in Russian historical science, taking into account the necessity to build a positive image of the state history and influence of the Soviet inheritance, in which collaboration was interpreted as a movement based solely on ideological thoughts. For a quite long time the Russian authorities tried to conceal the problem of collaboration of Soviet citizens with the Nazis during World War II since it did not fit into created victorious realities by the authority during war time. Therefore, vague nature of the concept of historiography and active interest of Russian society complicated the reconsideration of collaboration problem even more. The interpretation of collaboration became a major problem of Russian public policy of memory.

The object of the article is to describe the most important trends of scientific interpretation problem of collaboration in contemporary Russian historiography and determine the impact of Russian public policy of memory on the process of its creation.

Modern historical researches devoted to the problem of collaboration include a research experience of Soviet historical science and modern approaches of Western historiography. The interaction of such contradictory factors influenced the development of historical investigation, provoked debates among Russian scientists that escalated even more since they were socially important and under a direct control of the government.

Memorial law, including direction and content of researches on World War II, established the boundaries of scientific knowledge of the problems of collaboration and school narrative represented its expectations. Collaboration in Russian textbooks is depicted as a universal trend of the military times. Interpreting the collaboration issue the authors of Russian textbooks focused on the scale of exploitation of people and robbing material resources in the occupied territories, denying any neutral motives of cooperation of Soviet citizens with the enemy though.

The definition of "collaboration» caused a fierce discussion in modern Russian historiography; since quite many professional historians emotionally perceived practice of contacting Soviet citizens with the Nazis. The historians used a term with a less negative meaning than 'treason' and called it French term 'collaboration'. Debates on definition of 'collaboration' caused application of a more complicated characteristic of collaboration motives in modern Russian historiography. Most researches tend to consider different reasons for soviet citizens' collaboration 
with the Nazis such as a rejection of Soviet system and active participation on the side of the enemy to simply attempt to survive in a tough condition of occupation or captivity. Changes in interpretation of collaboration motives led to the review of collaboration typology. Another new trend in research of collaboration issue was to determine the number of this phenomenon. Soviet historians did not indicate the total number of collaborators emphasizing its insignificance.

Thus, the results of modern historical research by Russian historians discovered a possibility to distinguish cooperation from collaboration, applying a criterion of citizen interaction motive with the occupation regime. Therefore, the essence of cooperation is identified as a contact person's behavior that does not affect the struggle of his country with the aggressor. These actions are considered by Russian historians through a legal and moral aspect. However, the problem of treason during the Second World War in the works of Russian historians remained unclear, as unique and extraordinary conditions of military confrontation were neglected, instead they continued to research moralization and publicistics, without applying to the issues of collaboration and cooperation a principle of historicism.

Key words: collaboration, World War II, the German-Soviet war, Russian historiography.

Ирина СУХОВЕРСКАЯ, аспирантка Львовского национального университета имени Ивана Франко, кафедра истории Центральной и Восточной Европь,

(Украина, Львов)23anuri@gmail.com

\section{ПРОБЛЕМЫ ТРАКТОВКИ КОЛЛАБОРАЦИОНИЗМА В ГОДЫ ВТОРОЙ МИРОВОЙ ВОЙНЫ В СОВРЕМЕННОЙ РОССИЙСКОЙ ИСТОРИОГРАФИИ}

В статье охарактеризованы важнейшие тенденции научной трактовки проблемы коллаборачионизма в годы Второй мировой войны в современной российской историографии. Определены главные идеи и особенности историографического процесса, методы исторического исследования, влияние общественно-политических явлений на тематику и содержание исторических исследований. Определенное внимание сосредоточено на анализе взаимодействия современной российской историографии и государственной политики памяти. Определены перспективы научных исследований в этом сегменте фундаментальных исследований.

Ключевые слова: коллаборачионизм, Вторая мировая война, немеико-советская война, российская историография.

Постановка проблеми. Здобутки «архівної революції», залучення до наукових досліджень зарубіжних архівних та історіографічних джерел, застосування методологічних принципів світової історичної науки останньої чверті XX ст., розробка нових підходів до вивчення подій Другої світової війни спровокували зміни у тлумаченні проблеми колабораціонізму у російській історіографіï, за яких на початку 1990-х рр. дослідники здійснили спробу подолати політичні та ідеологічні бар'єри у трактуванні проблеми колабораціонізму. Ця проблема залишилася однією з найбільш політизованих тем у російській історичній науці, враховуючи необхідність побудови позитивного іміджу історії держави та вплив радянської спадщини, де колабораціонізм трактувався як рух, заснований винятково на ідейних помислах. Тривалий час російська влада намагалася приховати проблему співпраці радянських громадян з нацистами у роки Другої світової війни, оскільки вона зовсім не вписувалася у конструйовані владою переможні реалії та героїчні вчинки воєнного часу. Саме тому переосмислення проблеми колабораціонізму ускладнили невизначена сутність цього поняття в історіографії та активне зацікавлення російського суспільства. Трактування колабораціонізму стало значною проблемою державної політики пам'яті Росії, яка докладала чимало зусиль для консервації радянських оцінок подій і їх використання в ідеологічній обробці населення. У зв'язку з цим дискусії навколо співпраці радянських громадян з німецькими окупантами у російській історичній науці набули різких форм, зважаючи на їхнє суспільне значення та безпосередній контроль влади.

Аналіз досліджень. Проблема наукового трактування колабораціонізму виступила надзвичайно складною та багатоаспектною темою у сучасній російській історіографії, що стимулювало істориків до активного обговорення цієї проблематики в монографіях та періодичних виданнях. 
Дослідженням колабораціонізму в роки Другої світової війни займаються С. Дробязко (Дробязко, 1997: 127-134), М. Кірсанов (Кірсанов, 2001: 60-75), Б. Ковальов (Ковальов, 2004: 544), Є. Кринько (Кринько, 2009: 370), С. Кудряшов (Кудряшов, 1993: 84-98), О. Макаров (Макаров, 2011: 185-191), П. Полян (Полян, 2002: 896), М. Семиряга (Семиряга, 2000: 864), Р. Хісамутдінова (Хісамутдінова, 2013: 117-125), С. Шанцева (Шанцева, 2010: 184-188) та інші. Названі автори охарактеризували методологічні принципи, концепції та нові підходи до вивчення проблеми колабораціонізму, які сформувалися наприкінці XX ст. у російській історіографії, окреслили еволюційні зміни у сучасній російській історіографії, присвяченій проблемі колабораціонізму в роки Другої світової війни, визначили особливості викладу означеної проблематики у концепціях сучасної російської історіографії, зосередивши увагу на мотивах співпраці радянських громадян 3 нацистами. М. Семиряга (Семиряга, 2000: 864), С. Кринько (Кринько, 2009: 370) сформулювали поняття «колабораціонізм», розкрили причини та мотиви колабораціонізму як суспільно-політичного та соціально-економічного явища. П. Полян (Полян, 2002: 896), Б. Ковальов (Ковальов, 2004: 544) зосередили власний науковий аналіз на типах колабораціонізму та формах його прояву, визначили чисельність колабораціоністського руху. С. Кудряшов (Кудряшов, 1993: 84-98), О. Макаров (Макаров, 2011: 185-191), С. Шанцева (Шанцева, 2010: 184-188), Р. Хісамутдінова (Хісамутдінова, 2013: 117-125) охарактеризували стан вивчення колабораціонізму у сучасній російській історіографії, проаналізували вплив радянської історіографії на сучасне трактування колабораціонізму. Не зважаючи на численні дослідження колабораціонізму в роки Другої світової війни, поза увагою дослідників залишився вплив державної політики пам'яті на розвиток сучасної російської історіографії.

Мета статті - охарактеризувати найважливіші тенденції наукового трактування проблеми колабораціонізму у сучасній російській історіографії та визначити вплив державної політики пам’яті Росії на процес іiї створення.

Виклад основного матеріалу. Активний пошук російськими науковцями нових теоретичних та концептуально-методологічних засад трактування колабораціонізму, процес поступового впровадження гуманістичного та антропоцентричного підходів до вивчення мотивів співпраці радянських громадян з ворогом, «архівна революція», збагачення російської історичної науки надбаннями світової історіографії, формування історіографічного простору науковців Росії та російської діаспори, активізація досліджень історії Другої світової на регіональному рівні місцевими науково-дослідними центрами та установами, навчальними закладами, окремими істориками спровокували розширення проблемного поля, джерельної бази та дослідницького апарату сучасної російської історичної науки, яка відрізняється від радянської історіографії методологічним плюралізмом і намаганням синтезувати досягнення російської та зарубіжної історіографії. Таким чином, сучасні історичні дослідження, присвячені проблемі колабораціонізму, включили у себе дослідницький досвід радянської історичної науки та сучасні підходи західної історіографії. Взаємодія таких протилежних чинників впливу на розвиток історичних досліджень спровокувала дискусію серед російських науковців, яка набула різких форм, зважаючи на їхнє суспільне значення та безпосередній контроль влади (Никифоров; Невежин, 2007: 158; Шанцева, 2010: 184).

Державна політика пам'яті Росії зумовила жорстку ідеологічну спрямованість історичних досліджень, присвячених проблемі колабораціонізму, шляхом запровадження меморіальних законів та жорсткого контролю шкільного наративу. Меморіальні закони, в яких обумовлено напрям та зміст наукових досліджень про Другу світову війну, створили межі наукового пізнання проблеми колабораціонізму, а шкільний наратив репрезентував його очікувані результати. За таких умов найкраще ідеологічні рамки історичних досліджень відображено у російському шкільному наративі, який виступив вказівником напрямку розвитку історичних досліджень, присвячених проблемі колабораціонізму (Шанцева, 2010: 184).

Колабораціонізм у російських шкільних підручниках зображено як універсальну тенденцію воєнних років, характерну для всіх країн, які зазнали окупації та впровадження нацистського «нового порядку» (Левандовський, Щетинов, 1997: 221). Головний акцент при трактуванні проблеми колабораціонізму автори російського шкільного підручника зробили на характеристиці масштабів експлуатації населення та грабунку матеріальних ресурсів на окупованих територіях, запере- 
чуючи цим будь-які нейтральні мотиви у співпраці радянських громадян з ворогом (Левандовський, Щетинов, 1997: 212). Історики у шкільному підручнику аргументували винятково негативні мотиви співпраці з ворогом при аналізі руху Опору, зробивши особливий акцент на діяльності Російської визвольної армії під командуванням генерала О. Власова та організаціях українських, прибалтійських та кавказьких націоналістів (Данилов, Косулина, 2002: 198). Влучним є зауваження з цього приводу українського історика Ф. Турченка, який вказав, що у російському підручнику мало уваги приділяють представникам неросійських національностей СРСР, але таке враження зникає при розгляді розділу підручника «Велика вітчизняна війна. 1941 - 1945 рр.», в якому при характеристиці колабораціоністського руху згадали про прибалтійські, північнокавказькі, українські та татарські народи, які воювали на боці Німеччини (Ф. Турченко). При цьому явище колабораціонізму серед росіян у підручнику навіть не розглядалося, створивши враження, що тільки представники російського народу ніколи не співпрацювали з ворогом, а колабораціоністами були винятково «злочинці» інших національностей (Данилов, Косулина, 2002: 198). Таким чином, історичне знання про колабораціонізм у російській шкільній освіті, вирване із загального контексту історії Другої світової війни, формулює суб'єктивні неналежно обгрунтовані конструкції істориків задля збереження радянських традицій трактування проблеми колабораціонізму. У контексті цього сучасна історична російська шкільна освіта зазнала значного впливу державної політики пам'яті, яка не тільки заважає розвитку шкільного наративу у контексті досягнень сучасної історіографії, а й визначає напрям та зміст історичних досліджень російських науковців, які, спираючись на шкільний наратив, намагаються інтегрувати результати дослідження радянської та західної історіографії проблеми колабораціонізму, де особливе місце посідає питання дефініції співпраці радянських громадян з німецькими окупантами.

У сучасній російській історіографії визначення поняття «колабораціонізм» викликало запеклу дискусію, оскільки чимало професійних істориків не відступили від емоційного сприйняття практики контактів радянських громадян з нацистами. До 1990-х рр. термін «колабораціонізм» практично не використовувався істориками для означення співпраці з ворогом на радянській теритоpiї, а застосовувався тільки для характеристики подібних явищ на окупованих територіях Європи. Однак деякі історики зробили спробу відокремити зраду інтересів держави від форм співпраці людей з окупантами, виправданих обставинами, шляхом використання терміна менш вираженого негативним забарвленням. Вони замінили термін «зрада» французьким терміном «колабораціонізм», іноземне походження якого надало йому в російській історіографії нейтрального характеру у порівнянні з такими оцінним терміном, як «зрадник», що тривалий час домінувало у російській історіографії (Макаров, 2011: 185).

М. Семиряга, який одним 3 перших досліджував співпрацю радянських громадян 3 нацистами, сформулював визначення колабораціонізму - як сприяння громадян агресору у воєнний час на шкоду своїй державі і народу, що в умовах окупації характеризується як зрада батьківщини i, відповідно до міжнародного права, $є$ військовим злочином. Він розглянув контакти радянських громадян з нацистами як суспільно-політичне явище та запропонував вибірковий підхід для характеристики взаємодії радянських громадян з окупантами у роки Другої світової війни, надавши подвійного значення терміну «колабораціонізм»: 1) свідома зрада, що завдавала шкоди СРСР та заважала боротьбі з німецьким окупантом; 2) співпраця чи вимушена взаємодія з нацистським режимом, мета якої виживання. На думку історика, не можна кваліфікувати як зраду будь-які контакти з ворогом, оскільки за таких умов зрадниками можна вважати все населення, окуповане нацистами. Втім, подібне вживання термінів виявилося не позбавленим суперечностей у російській історіографії, оскільки межа між поняттями «зрадник» і «колабораціоніст» надзвичайно тонка і важко помітна (Семиряга, 2000: 5). С. Кудряшов відзначив, що перехід від нейтрального взаємодії до тіснішої співпраці відбувався досить просто, що унеможливлює вияв межі, яка відділяє взаємодію з окупаційними властями від співпраці з ними (Кудряшов, 1993: 91). Б. Ковальов взагалі не помітив різниці між взаємодією та співпрацею, охарактеризувавши діяльність колабораціоністів як зраду Батьківщини в моральному та правовому сенсі цього поняття (Ковальов, 2004: 480). Таким чином, російські історики не 
готові відмовитися від радянського трактування колабораціонізму, вважаючи його більш доцільним виразом правової оцінки співпраці з нацистами (Вишлёв, 2001: 195).

Дискусія стосовно визначення терміна «колабораціонізм» привела до застосування більш складної характеристики мотивів колабораціонізму у сучасній російській історіографії. Більшість дослідників схильні вважати, що причини співпраці радянських громадян 3 нацистами різноманітні - від неприйняття радянського ладу та активної участі у війні на боці супротивника до елементарного прагнення вижити в жорстких умовах окупації або полону. Прихильники радянської традиції трактування проблеми колабораціонізму скептично ставляться до тенденції у зарубіжній історіографії - зображати радянських колабораціоністів як жертв обставин, які були змушені піти на співпрацю з нацистськими окупаційними властями, борючись проти комуністичного режиму, однак вони визнають, що й такий мотив колабораціонізму мав місце (Кудряшов, 1997: 28).

Сучасні російські історики, відступивши від радянських кліше, схильні розглядати колабораціонізм радянських громадян як «спосіб виживання під п’ятою окупантів» (Кирсанов, Дробязко, 2001: 60). Вони охарактеризували психологічні мотиви колабораціонізму, серед яких страх перед жорстокістю нацистів, прагнення захистити і врятувати власні сім’ї, вижити у важких умовах окупації, закцентувавши увагу на психологічному тиску окупаційного режиму та нацистській пропаганді, в умовах яких частина радянських громадян втрачала звичні політичні і моральні орієнтири (Семиряга, 2000: 322). На думку російських істориків, за таких обставин більшість цивільного населення виявилося залученим до співпраці з ворогом обманом чи погрозами, натомість для військовополонених важливу роль зіграли нестерпні умови полону, оскільки керівництво СРСР відмовилося від співпраці з Червоним Хрестом та підписання Женевської конвенції «Про поводження з військовополоненими», що дало привід нацистам не виконувати Конвенцію щодо радянських військовополонених. П. Полян, проаналізувавши величезні масштаби смертності серед радянських вояків, зауважив, що вони перебували у нестерпних умовах (Полян, 2002: 137-138). Крім того, історики вказали, що полон розглядався радянським законодавством як злочин, оскільки в СРСР було видано Наказ Ставки Верховного Головного Командування Червоної армії від 16 серпня 1941 р. № 270 «Про відповідальність військовослужбовців за здачу в полон і залишення ворогові зброї», згідно з яким позиція радянського керівництва, прирівнювала всіх полонених до зрадників, підштовхнувши багатьох до вимушеної співпраці з німецькими властями (Макаров, 2001: 187).

Значну увагу при характеристиці мотивів військового колабораціонізму дослідники приділяли Російській визвольній армії генерала О. Власова, яка розглядалася у радянській історіографії символом зради. У сучасній російській історіографії дослідники схильні розглядати власовщину як політичне явище, що стало результатом низки причин, серед яких великі невдачі на фронті та страх радянських військовополонених перед розплатою за вимушений полон. Аналіз службової кар'єри Власова не дає підстав російським історикам стверджувати, що його співпраця 3 противником була продуманою і заздалегідь підготовленою (Хисамутдинова, 2013: 123). У трактуванні сучасної російської історіографії рішення Власова перейти на бік німців було викликане страхом повторити долю командувача військами Західного фронту генерала Д. Павлова. Саме тому Власов вирішив залучити на свій бік тих радянських солдатів і офіцерів, які мали напружені відносини зі сталінським режимом, і тим «забезпечити собі тепле місце в ієрархії німецького вермахту» (Семиряга, 2000: 327). Водночас російські історики намагалися розв'язати «проблему Власова» в рамках морально-етичної дилеми про те, ким був насправді генерал - зрадником чи героєм. На думку деяких істориків, які продовжили дотримуватися радянських традицій у трактуванні колабораціонізму, вимушена «стратегія виживання» через співпрацю радянських громадян з ворогом виступила проявом «третьої сили», так званого «антисталінського протесту». За таких умов власовський рух отримав моральне виправдання, незважаючи на те, що подібне трактування послужило підставою для заперечення правомірності назви «Вітчизняна війна» стосовно війни Радянського Союзу проти нацистської Німеччини та іï союзників. На їхню думку, виправдання колабораціонізму призводить до виправдання гітлерівської війни проти СРСР (Ковалёв, 2004: 521). Загалом більшість російських істориків дійшли згоди в тому, що Власов не був ідейним борцем зі Сталіним аж до полону і перейшов на бік ворога, рятуючи власне життя (Бахвалов, 1995: 156). 
Російські історики у дослідженнях, присвячених мотивам колабораціонізму, підкреслили, що активна військова співпраця з німецькими властями було особливо характерною для представників національних меншин Радянського Союзу, які зазнали впливу націоналістичних настроїв та розраховували на допомогу нацистської Німеччини на шляху побудови власної держави (Ковалёв, 2009: 162). На думку О. Сорокіної, особливі причини для переходу на бік противника існували у населення західних районів СРСР, які були пов'язані з радянською окупацією даних територій в 1939 - 1940 рр., масовими репресіями, а також давньої нелюбов'ю до росіян. У контексті цього історики проаналізували зміни в історіографії України та країн Балтії, в яких відбулася політична і юридична реабілітація колабораціоністів, які тепер розглядаються головними борцями за національну незалежність, де співпраця націоналістів з німецькою владою отримує позитивну оцінку як один із засобів боротьби проти більшовицької окупації, за національну незалежність. Російські історики не погодилися з колегами стосовно реабілітації колабораціонізму, оскільки націоналізм може виправдати колабораціонізм, але він не змінює його зрадницьку сутність, згідно 3 якою націоналісти, співпрацюючи з ворогом, скоювали злочини, передбачені законодавством СРСР (Сорокина, 2002).

Зміни у трактуванні мотивів співпраці з ворогом спричинили до перегляду типології колабораціонізму. Більшість дослідників запропонували виділяти форми колабораціонізму залежно від того, в якій сфері здійснювалася співпраця з противником. На думку С. Кудряшов, це-військова, політична й економічна співпраця. Крім того, вважаючи, що «між роботою у військових частинах і участю в бойових діях зі зброєю в руках існувала велика різниця», він запропонував розмежувати пасивний і активний військовий колабораціонізм залежно від участі у бойових діях (Кудряшов, 1993: 86). О. Макаров звернув увагу на класифікацію колабораціонізму Н. Романічевим, який виділив чотири основні форми співпраці з окупантами: 1) політичне співробітництво - діяльність національних комітетів (російських, українських, білоруських та ін.), які претендували на роль урядів; 2) адміністративне - участь у роботі створених окупаційною владою місцевих адміністративних органів; 3) господарське - робота в промисловості і сільському господарстві; 4) військове - служба зі зброєю в руках на боці Німеччини (Макаров, 2011: 189). М. Семиряга вказав, що діапазон форм прояву колабораціонізму досить великий, виділивши побутовий, адміністративний, економічний і військово-політичний. При цьому він зауважив, що не всі дані дії «можна кваліфікувати як зраду батьківщині, хіба тільки за винятком останнього типу, тобто військово-політичного колабораціонізму» (Семиряга, 2000: 11).

В. Малиновський запропонував класифікацію колабораціонізму за критерієм мотиву взаємодії 3 нацистами (Малиновський, 1996: 165). Застосування цього прийому дало змогу виокремити «свідомий» колабораціонізм, пов'язаний з неприйняттям з яких-небудь причин радянської держави і усвідомленим бажанням сприяти окупантам, i «вимушений», який виявляється через співпрацю та породжений зовнішніми стосовно суб'єкта обставинами. Від цих двох типів слід відокремлювати «псевдоколабораціонізм» - виконання тих чи тих функцій в окупаційній адміністрації або поліції учасниками народного опору (Кринько, 2004: 156).

Деякі історики застосували для класифікації колабораціонізму способи виявлення нових зон зради-співпраці. Б. Ковальов запропонував військовий, економічний, адміністративний, ідеологічний, інтелектуальний, духовний, національний, дитячий та статевий колабораціонізм (Ковалёв, 2004: 480). Таким чином, практика підходів сучасних російських істориків, які розглядають співпрацю з військовим супротивником не тільки як зраду (колабораціонізм), але й як соціальну проблему, пов'язану з різними стратегіями виживання людей в екстремальних умовах німецької окупації, доцільна. У цьому випадку головним критерієм відокремлення співробітництва від зради дійсно став такий мотив, як необхідність виживання (Семиряга, 2000: 680). Отже, застосування диференційованого підходу до колабораціоністів можна простежити в роботі низки російських істориків, які підкреслили необхідність індивідуального підходу до кожного конкретного випадку (Дробязко, 1997: 127).

Ще одним новим напрямом у дослідженнях проблеми колабораціонізму у сучасній російській історіографії стало визначення чисельності цього явища. Радянські історики не вказували загальної кількості колабораціоністів, підкресливши його незначні масштаби. Крім того, вони 
не поділяли позицій низки західних істориків, які вказали, що число радянських громадян, які співпрацювали з окупантами, становило близько одного мільйона осіб. Російські історики натомість вказували на те, що співпраця з ворогом в СРСР ніколи не досягала таких масштабів, як, наприклад, у Франції, Бельгії, Голландії. С. Кудряшов визначив частку активних військових колабораціоністів у кількості 250 - 300 тис. осіб, а загальну кількість колабораціоністів - в один млн осіб. На думку С. Дробязко, колабораціоністи становили 1,3 - 1,5 млн осіб. Н. Раманічев визначив частку колабораціоністів в кількості 1 - 1,5 млн осіб. Чисельність військових формувань колабораціоністів залишається предметом дискусій серед російських істориків; за різними даними, подібні формування могли налічувати від 280 - 300 тис. до 1,5 млн осіб. Основну масу осіб, які виявилися залученими до прямої або непрямої військової співпраці з ворогом, становили радянські військовополонені - понад 4 млн осіб (Хисамутдинова, 2013: 122).

Висновки. Отже, результати сучасних історичних досліджень російських істориків виявили можливість відокремити співпрацю від колабораціонізму, використовуючи як критерій мотив взаємодії радянських громадянин з окупаційним режимом. У цьому випадку сутність співпраці ідентифікується як контактне поводження особи, що не завдає шкоди боротьбі його батьківщини з представниками держави-агресора. Ці дії розглядаються російськими істориками у двох аспектах - правовому і моральному. Однак проблема колабораціонізму в роки Другої світової війни у сучасній російській історіографії залишилася до кінця не зрозумілою, оскільки російські історики не надали належної уваги унікальним і надзвичайним умовам військового протистояння, а продовжують займатися моралізуванням і публіцистикою, не застосовуючи до розгляду питань колабораціонізму та співпраці принципу історизму. Принцип історизму у російських істориків проявився тільки через моральний погляд радянського взірця на проблему взаємодії з нацистським режимом, оскільки вони висвітлили винятково «зрадницьку поведінку громадян», які взаємодіяли з окупантами. Російські історики надалі оцінюють вчинки радянської людини з позиції радянських людей зразка 1941 - 1945 рр. У контексті цього проблема колабораціонізму виявила емпіричну силу і водночас методологічну слабкість російської історіографії, яка не готова відмовитися від морально-етичних оцінок і категорій. Однак розгляд головних питань та окремих аспектів проблеми колабораціонізму в роки Другої світової війни переконав у наявності суттєвих позитивних зрушень у їі дослідженні та висвітленні, створення наукових концепцій, де історики намагалися сформувати аргументовану картину місця, ролі і значення російського народу в подіях і процесах воєнного часу. Проте, аналізуючи російську історіографію та іiї взаємодію $з$ державною політикою пам'яті, необхідно зауважити, що тема Другої світової війни залишається на контролі держави, яка обмежує повноцінний розвиток російської історіографії на законодавчому рівні, адаптуючи до нових реалій радянські оцінки колабораціонізму, що обмежує повноцінний розвиток російської історіографії, звужуючи можливості наукової діяльності.

\section{СПИСОК ВИКОРИСТАНИХ ДЖЕРЕЛ І ЛІТЕРАТУРИ}

Бахвалов, 1995 - Бахвалов А. Генерал Власов. Предатель или герой? // Звезда. 1995. № 6. С. 109-156.

Вишлёв, 2001 - Вишлёв О. Накануне 22 июня 1941 года: монография. Москва, 2001. 230 с.

Данилов, Косулина, 2002 - Данилов А., Косулина Л. История России, XX век: Учеб. для 9 кл. общеобразоват. учрежден. Москва: Просвещение, 2002. 336 с.

Дробязко, 1997 - Дробязко С. Советские граждане в рядах вермахта в рядах вермахта. К вопросу о численности // Великая Отечественная война в оценках молодых: Сб. статей студентов, аспирантов, молодых учених. Москва, 1997. С. 127-134.

Кирсанов, Дробязко, 2001 - Кирсанов Н., Дробязко С. Великая Отечественная война 1941 - 1945 гг.: национальные добровольческие формирования по разные стороны фронта // Отечественная история. 2001. № 6. С. 60-75.

Ковалёв, 2004 - Ковалёв Б. Нацистская оккупация и коллаборационизм в России. 1941 - 1944: монографія. Москва, 2004. 544 с.

Ковалёв, 2009 - Ковалёв Б. Коллаборационизм в России в 1941 - 1945 гг.: типы и формы: монографія. Великой Новгород, 2009. 370 с.

Кринько, 2004 - Кринько Е. Коллаборационизм в СССР в годы Великой Отечественной войны и его изучение в российской историографии // Вопросы истории. 2004. № 11. С. 153-164. 
Кудряшов, 1993 - Кудряшов С. Предатели, «освободители» или жертвы режима? Советский коллаборационизм $(1941$ - 1942) // Свободная мысль. 1993. № 14. С. 84-98.

Кудряшов, 1997 - Кудряшов С. Советский коллаборационизм в годы войны: вопросы историографии // Проблемы истории Великой Отечественной войны 1941 - 1945 гг. Самара, 1997. С. 24-32.

Левандовський, Щетинов, 1997 - Левандовський А., Щетинов Ю. Россия в ХХ веке: учеб. для 11кл. общеобразоват. учрежден. Москва: Просвещение, 1997. 384 с.

Макаров, 2011 - Макаров О. Коллаборационизм и сотрудничество в Великой отечественной войне // Вестник Нижегородского университета им. Н. И. Лобачевского. 2011. № 3. С. 185-191.

Малиновский, 1996 - Малиновский В. Кто он, российский коллаборационист: патриот или предатель? // Вопросы истории. 1996. № 11-12. С. 164-166.

Невежин, 2007 - Невежин В. СССР во Второй мировой войне: новейшая российская историография проблемы // Україна-Росія: діалог історіографій. Матеріали міжнародної конференції. Київ-Чернігів. 2007. C. $157-170$.

Никифоров - Никифоров Ю. Великая Отечественная война в зеркале «новой» историографии [Електронний ресурс]. Режим доступу: http://www.russianglobe.com/N75/Lulechnik.PravdaoZnameniPobedu.htm/.

Полян, 2002 - Полян П. Жертвы двух диктатур. Жизнь, труд, унижение и смерть советских военнопленных и остарбайтеров на чужбине и на родине: монографія. Москва, 2002. 896 с.

Семиряга, 2000 - Семиряга М. Коллаборационизм. Природа, типология и проявление в годы Второй мировой войны: монография. Москва, 2000. 864 с.

Сорокина, 2002 - Сорокина О. Этнические движение в СССР и вторая мировая война // История. 2002. № 6. [Електронный ресурс]. - Режим доступу: http://his.1september.ru/article.php?ID=200200602.

Турченко - Турченко Ф. «Общая история»: наука чи політика? [Електронний ресурс]. - Режим доступу: http://krasnews.at.ua/publ/rozpovidi_pro_zemljakiv/slovo_v_nauci/fedir_turchenko_obshhaja_istorija_nauka_chi_ politika_i/27-1-0-226.

Хисамутдинова, 2013 - Хисамутдинова Р. Проблема коллаборационизма в СССР в годы Великой Отечественной войны в современной российской историографии и зарубежной литературе // Вестник Оренбургского государственного педагогического университета. 2013. № 3. С. 117-125.

Шанцева, 2010 - Шанцева Е. Историография проблемы коллаборационизма в СССР в годы Великой Отечественной войны 1941 - 1945 гг. // Гуманитарные науки. История и политология. 2010. № 6. С. 284-288.

\section{REFERENCES}

Bakhvalov, 1995 - Bakhvalov A. General Vlasov. Predatel ili geroy? [General Vlasov. Traitor or hero?] // Zvezda. 1995. № 6. S. 109-156. [in Russian].

Vishlev, 2001 - Vishlev O. Nakanune 22 iyunya 1941 goda [On the eve of June 22, 1941]: monografiya. Moscow, 2001. 230 s. [in Russian].

Danilov, Kosulina, 2002 - Danilov A., Kosulina L. Istoriya Rossii, XX vek [History of Russia, the 20th century]: Ucheb. dlya 9 kl. obshcheobrazovat. uchrezhden. Moscow: Prosveshchenie, 2002. 336 s. [in Russian].

Drobyazko, 1997 - Drobyazko S. Sovetskie grazhdane v ryadakh vermakhta v ryadakh vermakhta. K voprosu o chislennosti [Soviet citizens in the ranks of the Wehrmacht in the ranks of the Wehrmacht. To the question of the number] // Velikaya Otechestvennaya voyna v otsenkakh molodykh: Sb. statey studentov, aspirantov, molodykh uchenikh. Moscow, 1997. S. 127-134. [in Russian].

Kirsanov, Drobyazko, 2001 - Kirsanov N., Drobyazko S. Velikaya Otechestvennaya voyna 1941 - 1945 gg.: natsionalnye dobrovolcheskie formirovaniya po raznye storony fronta [The Great Patriotic War of 1941 - 1945: national volunteer formations on different sides of the front] // Otechestvennaya istoriya. 2001. № 6. S. 60-75. [in Russian].

Kovalev, 2004 - Kovalev B. Natsistskaya okkupatsiya i kollaboratsionizm v Rossii. 1941-1944 [Nazi occupation and collaboration in Russia. 1941 - 1944]: monografiya. Moscow, 2004. 544 s. [in Russian].

Kovalev, 2009 - Kovalev B. Kollaboratsionizm v Rossii v 1941 - 1945 gg.: tipy i formy [Collaboration in Russia in 1941 - 1945: Types and Forms]: monografiya. Veliky Novgorod, 2009. 370 s. [in Russian].

Krinko, 2004 - Krinko Ye. Kollaboratsionizm v SSSR v gody Velikoy Otechestvennoy voyny i ego izuchenie v rossiyskoy istoriografii [Collaboration in the USSR during the Great Patriotic War and its study in Russian historiography] // Voprosy istorii. 2004. № 11. S. 153-164. [in Russian].

Kudryashov, 1993 - Kudryashov S. Predateli, «osvoboditeli» ili zhertvy rezhima? Sovetskiy kollaboratsionizm (1941 - 1942) [Traitors, «liberators» or victims of the regime? Soviet collaborationism (1941 - 1942)] // Svobodnaya mysl. 1993. № 14. S. 84-98. [in Russian]. 
Kudryashov, 1997 - Kudryashov S. Sovetskiy kollaboratsionizm v gody voyny: voprosy istoriografii [Soviet collaboration in the war years: issues of historiography] // Problemy istorii Velikoy Otechestvennoy voyny 1941 1945 gg. Samara, 1997. S. 24-32 [in Russian].

Levandovskiy, Shchetinov, 1997 - Levandovskiy A., Shchetinov Yu. Rossiya v XX veke [Russia in the twentieth century]: ucheb. dlya 11kl. obshcheobrazovat. uchrezhden. Moscow: Prosveshchenie, 1997. 384 s. [in Russian].

Makarov, 2011 -Makarov O. Kollaboratsionizm i sotrudnichestvo v Velikoy otechestvennoy voyne [Collaboration and cooperation in the Great Patriotic War] // Vestnik Nizhegorodskogo universiteta im. N. I. Lobachevskogo. 2011. № 3. S. 185-191. [in Russian].

Malinovskiy, 1996 - Malinovskiy V. Kto on, rossiyskiy kollaboratsionist: patriot ili predatel? [Who is he, a Russian collaborator: a patriot or a traitor?] // Voprosy istorii. 1996. № 11-12. S. 164-166. [in Russian].

Nevezhin, 2007 - Nevezhin V. SSSR vo Vtoroy mirovoy voyne: noveyshaya rossiyskaya istorigorafiya problemy [USSR in the Second World War: the newest Russian historiography of the problem] // Ukraïna-Rosiya: dialog istoriografiy. Materiali mizhnarodnoï konferentsiï. Kiev-Chernihiv. 2007. S. 157-170. [in Russian].

Nikiforov - Nikiforov Yu. Velikaya Otechestvennaya voyna v zerkale «novoy» istoriografii [The Great Patriotic War in the mirror of the «new» historiography] [Yelektronniy resurs]. Rezhim dostupu: http://www.russianglobe. com/N75/Lulechnik.PravdaoZnameniPobedu.htm/ [in Russian].

Polyan, 2002 - Polyan P. Zhertvy dvukh diktatur. Zhizn, trud, unizhenie i smert sovetskikh voennoplennykh i ostarbayterov na chuzhbine i na rodine [Victims of two dictatorships. Life, work, humiliation and death of Soviet POWs and Ostarbeiters in a foreign land and in their homeland]: monografiya. Moscow, 2002. 896 s. [in Russian].

Semiryaga, 200 - Semiryaga M. Kollaboratsionizm. Priroda, tipologiya i proyavlenie v gody Vtoroy mirovoy voyny [Collaboration. Nature, typology and manifestation during the Second World War]: monografiya. Moscow, 2000. 864 s. [in Russian].

Sorokina, 2002 - Sorokina O. Etnicheskie dvizhenie v SSSR i vtoraya mirovaya voyna [Ethnic Movement in the USSR and World War II]. - Istoriya. 2002. № 6. [Elektronnyi resurs] Rezhim dostupu: http://his.1september.ru/ article.php?ID=200200602 [in Russian].

Turchenko - Turchenko F. «Obshchaia ystoryia»: nauka chy polityka? [«General History»: Science or Politics?] [Elektronnyi resurs] // Rezhym dostupu: http://krasnews.at.ua/publ/rozpovidi_pro_zemljakiv/slovo_v_nauci/fedir_ turchenko_obshhaja_istorija_nauka_chi_politika_i/27-1-0-226 [in Ukrainian].

Khisamutdinova, 2013 - Khisamutdinova R. Problema kollaboratsionizma v SSSR v gody Velikoy Otechestvennoy voyny v sovremennoy rossiyskoy istoriografii i zarubezhnoy literature [The Problem of Collaboration in the USSR during the Great Patriotic War in Contemporary Russian Historiography and Foreign Literature] // Vestnik Orenburgskogo gosudarstvennogo pedagogicheskogo universiteta. 2013. № 3. S. 117-125. [in Russian].

Shantseva, 2010 - Shantseva Ye. Istoriografiya problemy kollaboratsionizma v SSSR v gody Velikoy Otechestvennoy voyny $1941-1945 \mathrm{gg}$. [Historiography of the problem of collaborationism in the USSR during the Great Patriotic War of 1941 - 1945] // Gumanitarnye nauki. Istoriya i politologiya. 2010. № 6. S. 284-288. [in Russian].

Стаття надійшла до редакиіï 6.02.2018 p. 